\title{
Rotator cuff repair: challenges and solutions
}

This article was published in the following Dove Press journal:

Orthopedic Research and Reviews

9 July 2015

Number of times this article has been viewed

\section{Michael H Amini' \\ Eric T Ricchetti ${ }^{\prime}$ \\ Joseph P lannotti \\ Kathleen A Derwin ${ }^{2}$ \\ 'Orthopaedic and Rheumatologic Institute, Cleveland Clinic, Cleveland, $\mathrm{OH}$, USA; ${ }^{2}$ Department of Biomedical Engineering and Orthopaedic Surgery, Cleveland Clinic Lerner Research Institute, Cleveland, OH, USA}

Correspondence: Kathleen A Derwin Department of Biomedical Engineering, Cleveland Clinic Lerner Research Institute, 9500 Euclid Avenue, ND20, Cleveland, OH 44I95, USA

$\mathrm{Tel}+\mathrm{I} 2164455982$

Fax + I 2164449198

Email derwink@ccf.org
Abstract: Each year, 250,000 rotator cuff repairs are performed in the United States at a cost of $\$ 3$ billion. Despite advancements in repair techniques and rehabilitation, $20 \%-70 \%$ of repairs continue to undergo structural failure; however, there is a poor correlation between clinical and structural outcomes, both before and after surgery. "Failure in continuity", or retraction of the repair site without a structural defect, is likely a common phenomenon after rotator cuff repair, and this retraction of the myotendinous unit and interposing scar tissue may be one explanation for the discordance between clinical and structural outcomes. Scaffolds, both synthetic and biologic, have shown promise in both augmentation of repairs and interposition of irreparable tears, but most studies are small retrospective case series without control groups. Future efforts will need to determine the ideal indications for use, methods of application, and comparative effectiveness between the devices. Platelet-rich plasma also has potential to improve rotator cuff healing, but current limitations include the significant variation in preparation methods, biologic makeup, and application methods. Future work may help us understand whether application of platelet-rich plasma and its growth factors should be done at the time of surgery or later during a more advanced stage of healing. Regardless of the device or technique, mechanical and/or biologic augmentation of rotator cuff repairs requires the surgeon to be technically proficient in its use and aware of its associated increased operative time and cost. In order to justify the use of these technologies and their associated incremental cost, we must demonstrate efficacy in improving both clinical and structural outcomes.

Keywords: rotator cuff, repair, tear, augmentation, scaffold, biologic, PRP

\section{Introduction}

Rotator cuff tears (RCT) are the number one cause of shoulder disability in patients older than 65 years of age and affect $40 \%$ of the population older than 60 years of age. ${ }^{1,2}$ In the United States alone, 250,000 patients undergo rotator cuff repair (RCR) annually, at an estimated cost of $\$ 3$ billion. ${ }^{2,3}$ Reports on structural outcomes using advanced imaging such as ultrasound (US) or magnetic resonance imaging (MRI) show that $20 \%-70 \%$ of RCRs fail by retearing, despite advances in surgical techniques and postoperative rehabilitation. ${ }^{4-6}$ Many studies suggest that patients with structurally intact repairs have better patient-reported outcomes (PROs), ${ }^{6-15}$ range of motion, ${ }^{16-19}$ and strength ${ }^{8,9,12,13,16-20}$ than those with structural retears, although a recent meta-analysis demonstrated that these differences are too small to be clinically meaningful. ${ }^{21}$ Furthermore, patients with structurally intact repairs can present with persistent weakness and dysfunction that would imply a failed repair, ${ }^{22-29}$ while patients with structurally failed repairs often show improved clinical outcomes in pain and 
function that would imply a healed repair. ${ }^{30-33}$ These weak correlations between structural integrity and measurable clinical outcomes limit investigative efforts and advances in the diagnosis and treatment of patients with RCTs. Here, we examine current definitions of rotator cuff "healing" and explore current solutions to reduce retear rates by mechanical and biological augmentation of the repair site.

\section{What is "healing"?}

In 1991, Harryman et $\mathrm{al}^{16}$ brought attention to structural healing of repairs of the rotator cuff when they evaluated structural integrity by US and correlated this with functional results. The authors used US to characterize initial and recurrent tear size as type 0 for intact tendons, type $1 \mathrm{~A}$ for partial thickness tears, type 1B for full thickness tears of the supraspinatus, type 2 for tears of the supraspinatus and infraspinatus, and type 3 for tears of the supraspinatus, infraspinatus, and subscapularis. They noted that patients with healed tendons had better function and less pain than those with recurrent defects and that $80 \%$ of type $1 \mathrm{~B}$ tears healed compared to $57 \%$ of type 2 tears and $32 \%$ of type 3 tears. In addition to initial tear size, older age and revision surgery were correlated with repair failure.

In 2005, Sugaya et $\mathrm{al}^{34}$ expanded the definition of structural integrity in their study that used MRI to evaluate single- and double-row repairs, and this classification has been used widely since. Assessed on postoperative T2-weighted images, type I indicates sufficient thickness with homogeneously low intensity on each image, type II indicates sufficient thickness with a partial high-intensity area, type III indicates insufficient thickness without discontinuity, type IV indicates the presence of a minor discontinuity in more than one slice on each image suggesting a small tear, and type $\mathrm{V}$ indicates the presence of a major discontinuity on each image suggesting a medium or large tear. A follow-up study from the same group revealed that patients with larger recurrent defects, specifically those with type $\mathrm{V}$ repairs, had worse outcomes. $^{22}$

However, patients with structurally intact repairs can present with persistent weakness and dysfunction that would imply a failed repair, ${ }^{22-29}$ despite a lack of imaging evidence to support a failure. One explanation may be that the repair has undergone "failure with continuity", defined as failure of the initial surgical construct by any means, including elongation of the muscle-tendon unit, without a full-thickness anatomic defect. Although imaging reveals an anatomically intact tendon, at least some portion of the tissue connecting the rotator cuff muscle to the bone is a tendon-like material that is of variable thickness, resulting in the myotendinous junction being medially displaced from its anatomic or initially repaired location. The lack of restoration of the normal length and location of the myotendinous unit associated with the presence of tissue has the same functional effect of a failed repair with a recurrent full thickness tissue defect (Figure 1).

Evidence for "failure with continuity" following RCR has been shown in two recent studies. ${ }^{35,36}$ Baring et $\mathrm{al}^{35}$ used metal suture markers to measure tendon retraction in ten patients after RCR. They noted that tendon retraction occurs during the second and third postoperative months when patients undergo the most intense physical therapy. Mean tendon retraction was $7.0 \mathrm{~mm}$, and nine of ten patients underwent retraction of $4.0 \mathrm{~mm}$ or more.

Similarly, McCarron et $\mathrm{al}^{36}$ analyzed repair site elongation in a prospective cohort of 14 patients, with full-thickness RCT treated with a SutureBridge repair construct and a standardized postoperative rehabilitation protocol. Retraction was measured on serial computed tomography (CT) scans using tantalum beads placed within the rotator cuff tendons at the time of repair, and structural integrity was measured on serial MRIs. Both CT and MRI were performed at 6, 12, 26 , and 52 weeks postoperatively to correlate retraction and defect formation. All patients underwent retraction of the repaired tendon, while only $30 \%$ had a recurrent defect at final follow-up. Mean retraction at 52 weeks was similar in those with structurally intact repairs compared to those with recurrent defects, $15.2 \mathrm{vs} 18.3 \mathrm{~mm}$. In addition, $80 \%$ of the tendon retraction after RCR occurred in the first 12 weeks, suggesting that repair failures - with or without a recurrent defect - occur early in the postoperative period. ${ }^{36}$ This conclusion is supported by Miller et $\mathrm{al}^{37}$ who showed that seven of nine retears occurred within 3 months of repair, while the other two occurred between 3 and 6 months. Similarly, Iannotti et $\mathrm{al}^{38}$ found that 8 of 19 structural failures of RCR occurred between 0 and 12 weeks after repair and 10 of 19 occurred between 12 and 26 weeks, and Hernigou et al ${ }^{39}$ found that 7 of 15 structural failures seen in the first 6 months were evident by 3 months.

These studies show that RCR failure occurs frequently, early, and with or without an anatomic full thickness tissue defect, and together suggest the need for strategies to augment the repair construct. It is likely that failures that occur in the first 4-6 weeks represent an inability of the surgical construct to mechanically maintain the integrity of the repair site. During this acute and subacute postoperative period of hemostasis and inflammation, biologic factors likely play little 

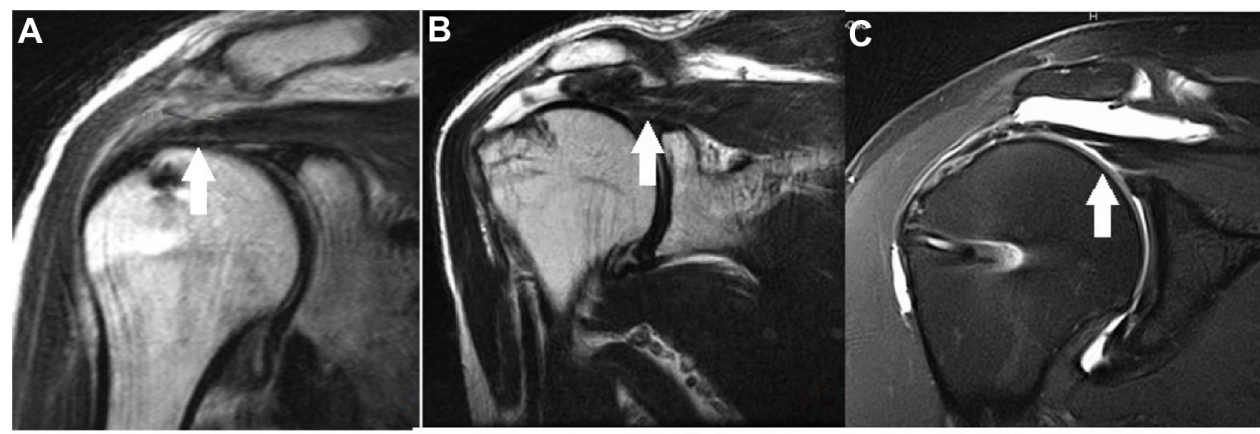

D

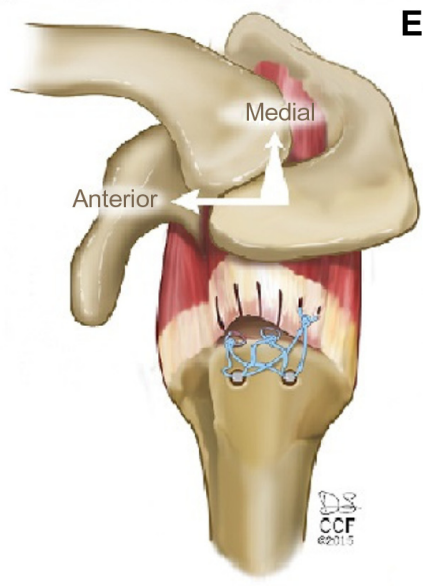

E

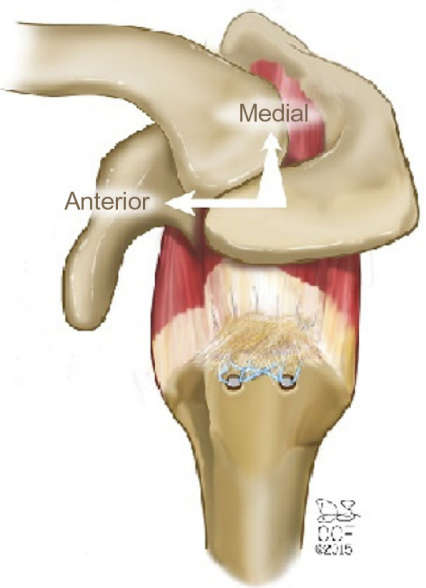

Figure I Modes of rotator cuff failure.

Notes: (A) Intact repair on MRI. Note the position of the musculotendinous (MT) junction at the midpoint of the humeral head. (B) Failure with defect on MRI. Note the defect at the greater tuberosity and the significantly retracted position of the MT junction. (C) Failure with continuity on MRI. Note the continuous tissue extending to the greater tuberosity despite significant retraction of the MT junction. White arrows in A-C show position of the MT junction. (D) Illustration of failure with defect. (E) Illustration of failure with continuity. Illustrations by David Schumick, BS, CMI. Reprinted with the permission of the Cleveland Clinic Center for Medical Art and Photography (c) 2015. All Rights Reserved.

Abbreviation: MRI, magnetic resonance imaging.

role in the healing process and probably contribute little to the strength of the repair. Mechanical augmentation, in the form of a scaffold, may be able to minimize these early, mechanical failures. In contrast, later failures, particularly those in the 3-6 months period as the patient stresses the repair site while working to regain motion and strength, likely represent a biologic failure to heal. Biologic augmentation, in the form of platelet-rich plasma (PRP) or cell seeding, may offer a means to improve the quality or rate of healing. Further, a scaffold may offer a means to deliver these biologic therapies, as well as mechanically protect and stabilize the healing repair construct to facilitate their activity. Better understanding of biologic tendon healing and the timeline of the reparative process that occurs after surgery will serve to guide our efforts to mechanically and biologically augment RCRs.

\section{Solutions}

Given the large number of RCRs performed annually and the high rate of structural failure, there is a need to augment the repair site by mechanically reinforcing it and by biologically enhancing the rate and quality of the healing process.
Current techniques available for use in clinical practice include the application of scaffolds, both biologic and synthetic, and the use of PRP.

\section{Scaffolds}

Scaffold devices for augmentation of RCR exist in the form of extracellular matrix (ECM) and synthetic polymers. Both ECM and synthetic scaffolds work to mechanically off-load the repair site at time-zero and during the initial period of host healing after repair. ECM scaffolds also provide a chemically and structurally instructive setting to biologically influence the rate and quality of tendon healing. ${ }^{40}$ Nonhuman-derived ECM and synthetic devices must undergo the 510(k) regulatory process of the US Food and Drug Administration (FDA) for marketing as medical devices. Clearance does not require proof of efficacy but, rather, requires proof of equivalence to other devices in performance, biocompatibility, safety, stability, sterility, and packaging. In contrast, human-derived ECM scaffolds are considered human tissue for transplantation and require no clearance from the FDA if minimally manipulated and used homologously. 


\section{Immune responses to scaffolds}

ECM scaffolds induce histologic and morphologic responses in the host depending on species and tissue of origin, processing, terminal sterilization, and the loading environment. Porcine small intestine submucosa (SIS) scaffolds elicit a macrophage immune response. ${ }^{41,42}$ Cross-linked scaffolds elicit giant cells, chronic inflammation, and poorly organized fibrous tissue. ${ }^{41}$ The immune response to other ECM devices is less defined, as some may undergo slower remodeling and some degree of incorporation with host tissue. Synthetic scaffolds elicit responses depending on the material composition and morphology, including size, shape, porosity, and roughness. ${ }^{41,42} \mathrm{~A}$ more indepth discussion of the host immune response to ECM scaffolds can be found in prior reviews on this subject. ${ }^{41}$

\section{Cadaveric studies on scaffolds}

The degree to which a scaffold can mechanically augment the repair site depends on the material, geometry, and suture retention properties. Variables that the surgeon controls include the number, type, and location of sutures, and the pretensioning of the graft at the time of fixation. The mechanical augmentation will diminish as the scaffold degrades during the healing period, though this would ideally occur at the same time or later than healing of the host tissue and remodeling of the graft. ${ }^{41,42}$

McCarron et al ${ }^{43}$ evaluated poly-L-lactide grafts for augmentation of repairs in human cadaver shoulders. Yield load and ultimate load were significantly improved compared to nonaugmented repairs, and 7 of 20 augmented repairs failed at the suture-tendon interface compared to 17 of 20 nonaugmented repairs. ${ }^{43}$ Barber et a ${ }^{44}$ also demonstrated improved time-zero failure load in a human cadaveric model of RCR using human dermal allograft compared to standard RCR. They noted that failure strengths improved from $273 \pm 116 \mathrm{~N}$ for nonaugmented repairs to $325 \pm 74 \mathrm{~N}$ for augmented repairs, and 6 of 10 augmented repairs failed at the suture-tendon interface compared to 8 of 10 nonaugmented repairs. ${ }^{44}$ In another human cadaver study, McCarron et al also demonstrated improved mechanical properties of augmentation with a fascia lata patch reinforced with poly-L-lactic acid. Gap formation after 1,000 cycles was $4.7 \mathrm{~mm}$ in augmented repairs compared to $7.3 \mathrm{~mm}$ in nonaugmented repairs, and all augmented repairs were intact at 1,000 cycles compared to only 6 of 9 nonaugmented repairs. ${ }^{45}$ Together, these studies demonstrate the potential for graft augmentation to improve the mechanical properties of the rotator cuff tendon repair, at least at the time of surgery.
Importantly, Sahoo et $\mathrm{al}^{46}$ showed that acellular human dermis grafts underwent significant and unrecoverable elongation at low physiologic loads. The study also showed that preconditioning the grafts by cyclical stretching, use of reverse cutting needles for suture fixation, and application of about $20 \mathrm{~N}$ of pretensioning at the time of application in situ reduced the compliance of the graft. ${ }^{46}$ This information reinforces the importance of the method of application of the graft on its performance in augmenting the repair site.

\section{Clinical studies on scaffolds}

Although the FDA has approved scaffolds for use in augmentation of completed repairs, there is a relatively even split in the number of series using grafts to augment fully reparable tears compared to using grafts as interposition devices in partial repairs or irreparable tears. Most clinical series with the use of scaffolds in RCR are retrospective case series without control groups, include small sample sizes, and have relatively short-term follow-up. (Tables 1 and 2) Through a systematic review of the MEDLINE database and associated bibliographies, we identified all clinical series reporting on the use of commercially available scaffolds for augmentation or interposition of RCR as of March 2015, and these are reviewed below.

The first clinical series of ECM scaffolds included a noncross-linked porcine SIS, Restore Orthobiologic Implant (DePuy, Warsaw, IN, USA). ${ }^{47-49}$ Two studies, including a prospective randomized trial from our institution, revealed a severe, aseptic, postoperative inflammatory reaction in $20 \%-30 \%$ of patients receiving the device, in addition to no benefit in functional or structural outcomes. ${ }^{47,48}$ As a result, the American Academy of Orthopaedic Surgeons (AAOS) recommends against the use of noncross-linked porcine SIS grafts. ${ }^{50}$

Two retrospective case series on a cross-linked dermis scaffold, Zimmer Collagen Repair (Zimmer, Warsaw, IN, USA), reported mixed results, with one noting good functional results and structural integrity and another noting a high rate of graft disruption and aseptic inflammatory reactions. ${ }^{51,52}$ Several retrospective case series using noncrosslinked human dermis scaffolds, such as GraftJacket (Wright Medical, Arlington, TX, USA), demonstrate improved patient outcomes when used for either augmentation or interposition. ${ }^{53-56} \mathrm{~A}$ recent prospective randomized controlled trial compared augmentation of chronic two-tendon tears with noncross-linked human dermis to standard repair without augmentation. ${ }^{57}$ Functional scores, as assessed by the American Shoulder and Elbow Surgeons (ASES) Score 


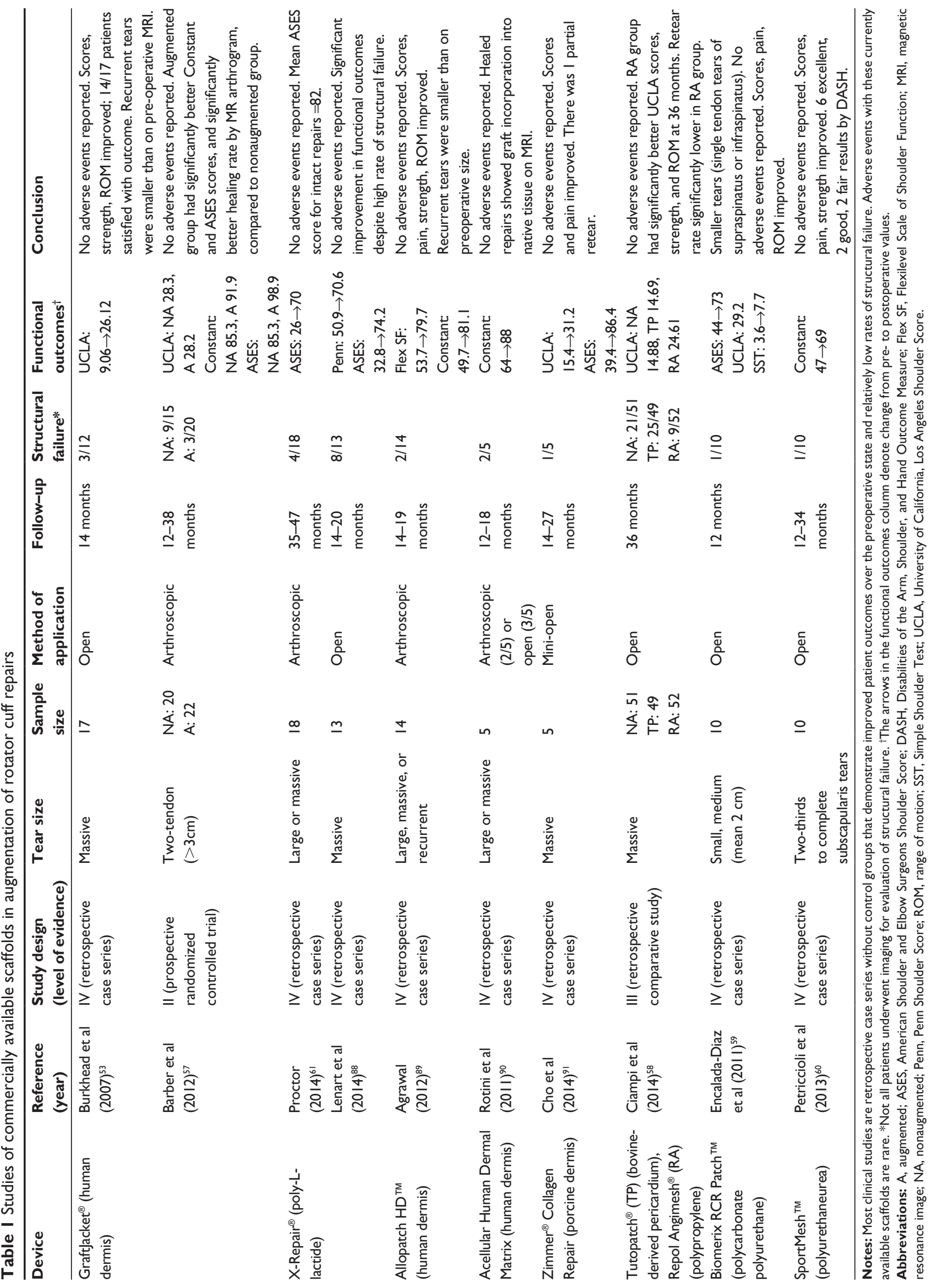




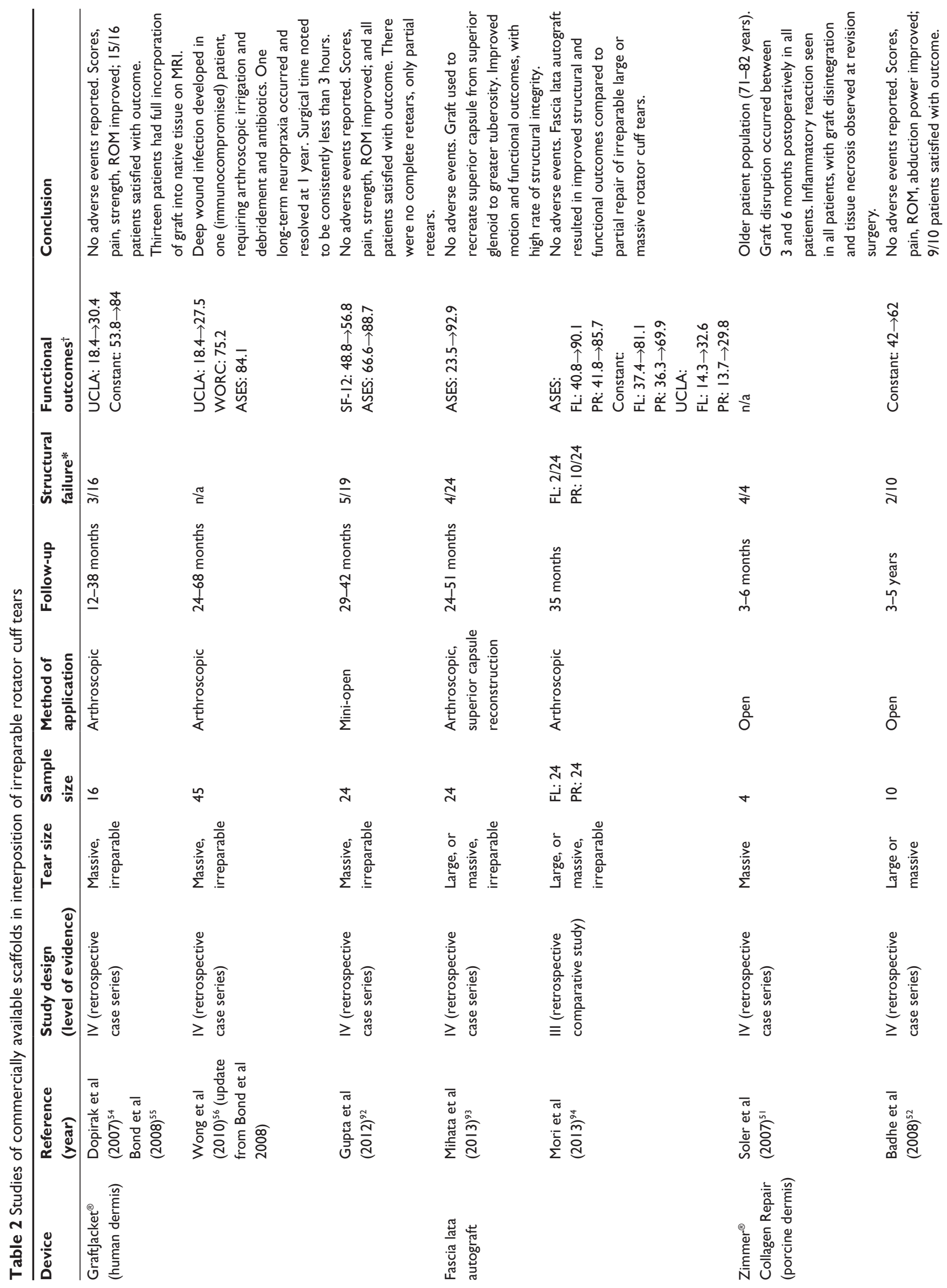



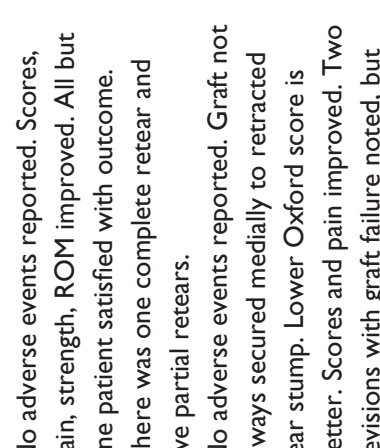

\begin{tabular}{|c|}
\hline 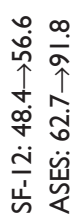 \\
\hline
\end{tabular}

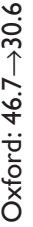

ลี

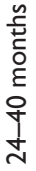

$\stackrel{\frac{1}{2}}{\frac{1}{2}}$

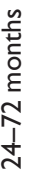

$\bar{\varpi}$
$\stackrel{0}{0}$
$\frac{1}{5}$
$\frac{1}{\Sigma}$

ญั

৯

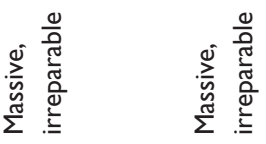

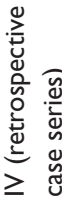

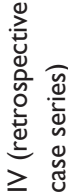

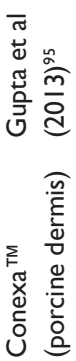

政 and the Constant Shoulder Score, were significantly better in the augmented group, and MRI evaluation at 1-2 years demonstrated significantly higher rate of healed repairs in the augmented group, $85 \%$ compared to $40 \%$. There were no adverse events noted.

Several synthetic grafts have been examined in retrospective case series, ${ }^{58-62}$ and similar to other devices, patients experienced improved clinical outcomes and a low rate of structural failure. One study comparing augmentation with a polypropylene mesh, Repol Angimesh (Angiologica, Pavia, Italy), to bovine pericardium, Tutopatch (Med\&Care, Gdynia, Poland), and to nonaugmented repairs demonstrated better outcomes and less structural failures $(17 \%, 51 \%$, and $41 \%$, respectively) with the synthetic mesh. ${ }^{58}$

Many available scaffolds have never been evaluated in the peer-reviewed literature, and many of the studies that do exist are case series with small sample sizes and no control groups of standard, nonaugmented repairs. These studies include a wide range of devices (allografts, xenografts, and synthetic grafts), indications (augmentation for different size tears, or interposition for irreparable tears), and outcomes (various functional outcome tools, different imaging modalities to evaluate structural integrity). Higher quality studies are needed to elucidate what size tears benefit from augmentation or interposition, open or arthroscopic application, and which devices improve structural and functional outcomes with a minimal risk profile.

\section{PRP}

Because platelets are naturally involved in hemostasis and thrombosis during the early inflammatory phase of healing and because platelets house many growth factors involved in healing, the use of a platelet concentrate in RCR is appealing. PRP has been used to biologically augment healing after injury and repair in other areas of dentistry, maxillofacial surgery, plastic surgery, and orthopedic surgery. ${ }^{63-66} \mathrm{By}$ concentrating the growth factors believed to be responsible for the healing process and reintroducing them to the site of injury, PRP is used to enhance recruitment, proliferation, and differentiation of regenerative cells in tissue repair. ${ }^{67}$

\section{PRP preparation and mechanism of action}

Platelets contain $\alpha$ granules that, when activated, release adhesive proteins, clotting factors, and growth factors. ${ }^{67,68}$ These growth factors (such as platelet-derived growth factor, vascular-derived growth factor, transforming growth factor- $\beta 1$, basic fibroblast growth factor, epidermal growth factor, hepatocyte growth factor, and insulin-like 
growth factor-1) are among those known to play a role in cell proliferation and differentiation, chemotaxis, angiogenesis, and ECM production, and they can be expected to influence tendon healing. ${ }^{67,69-71}$

PRP is an autologous blood concentrate that contains at least 1 million platelets per microliter, 4-7 times that of whole blood. ${ }^{72}$ However, the amount of growth factors present varies significantly between formulations, between individuals, and even between samples taken from the same individual. Even when using the same preparation method and the same patient's blood, the end product is highly variable in its platelet and leukocyte concentration. In fact, a patient's platelets may fail to concentrate with one preparation system but successfully concentrate with another. ${ }^{68,73}$

A recent qualitative classification system allows comparison between preparations and proposes consistent terminology. ${ }^{74}$ Three factors, leukocyte content, exogenous platelet activation, and the presence of a strong fibrin architecture, define the six categories. Leukocytes in the product signify the presence of inflammatory cytokines and matrix metalloproteinases, in addition to the growth factors from the platelets. ${ }^{68}$ Exogenous activation typically involves combining the concentrate with calcium chloride or thrombin immediately before administration to initiate platelet activation, clot formation, and the release of growth factors from $\alpha$ granules. ${ }^{72}$ Typical formulations release $70 \%$ of their growth factors within 10 minutes and $100 \%$ within 1 hour. ${ }^{75}$ A strong fibrin architecture, in the form of a platelet-rich fibrin (PRF) matrix, allows delayed growth factor release over 5-7 days. A second centrifugation in the presence of calcium chloride leads to the formation of the PRF matrix. ${ }^{72}$ Understanding how these three factors affect the end product will allow clinicians and scientists to better understand the effect of different PRP products on the healing process.

\section{Clinical studies on PRP use in RCR}

In contrast to the literature on scaffolds in augmentation of RCR, high-quality evidence on the use of PRP in RCR exists, albeit all have small sample sizes and only a few preparation methods have been investigated. Eight prospective randomized trials have compared RCR augmented with PRP to standard RCR (Table 3). ${ }^{76-83}$

Three prospective randomized trials utilized a PRF matrix from the Cascade Medical FIBRINET system (Musculoskeletal Transplant Foundation, Edison, NJ, USA) and interposed it at the tendon-bone interface during arthroscopic RCR. All studies demonstrated no difference in structural integrity. Regarding functional outcomes at final follow-up, Castricini et $\mathrm{al}^{76}$ and Rodeo et $\mathrm{al}^{80}$ showed no difference, while Weber et al $^{82}$ showed worse University of California Los Angeles (UCLA) scores. Two retrospective studies did demonstrate differences in structural healing, one demonstrating less failures, ${ }^{84}$ with another demonstrating more failures. ${ }^{85}$

Similarly, Gumina et $\mathrm{al}^{77}$ used a platelet-leukocyte membrane (PLM) from the RegenKit system (Regen Lab, Le Mont-Lausanne, Switzerland) in a prospective randomized trial. They demonstrated a lower rate of structural failure in the PLM group, but no difference in functional outcomes.

The use of two other products, a PRP product from the Gravitational Platelet Separation (GPS) II (Biomet, Warsaw, IN, USA) and a PRP gel from the COBE Spectra LRS Turbo (CaridianBCT, Lakewood, CO, USA), has resulted in a lower rate of structural failure in randomized trials; however, neither resulted in differences in functional outcomes. ${ }^{78,79} \mathrm{On}$ the other hand, the use of fibrin-rich PRP from the Vivostat PRF system (Vivostat A/S, Alleroed, Denmark) or plasma rich in growth factors from the PRGF System 1 (BTI Biotechnology Institute, Vitoria-Gasteiz, Spain) resulted in no differences in structural integrity or functional outcomes in randomized trials. ${ }^{81,83}$

An up-to-date meta-analysis of prospective randomized controlled trials of PRP in RCR demonstrated no differences in structural integrity or functional outcomes. ${ }^{86}$ Despite relatively high-quality studies, the meta-analysis included six different products, relatively small sample sizes, and short-term follow-up of around 1-3 years. Though in vitro studies suggest that PRP holds promise in tendon healing, clinical studies have failed to demonstrate improved outcomes. However, further in vitro and animal studies are needed to investigate methods of preparation, activation, and application before more widespread clinical investigation and use.

\section{Summary and future directions}

Despite a growing body of research and numerous FDAcleared scaffold and PRP products intended to improve healing rates after RCR, limited evidence exists to support their efficacy, and wide-spread clinical adoption has not occurred to date. Mechanical and biologic augmentation strategies, including the emerging use of cell-based therapies, ${ }^{39,87}$ require additional surgical expertise and operative time. In order to justify reimbursement for these additional costs, we must prove that these efforts will lead to a substantial change in outcomes for our patients. The appropriate indications, optimal timing and technique of application, and best products must be determined, and our definition of rotator cuff 


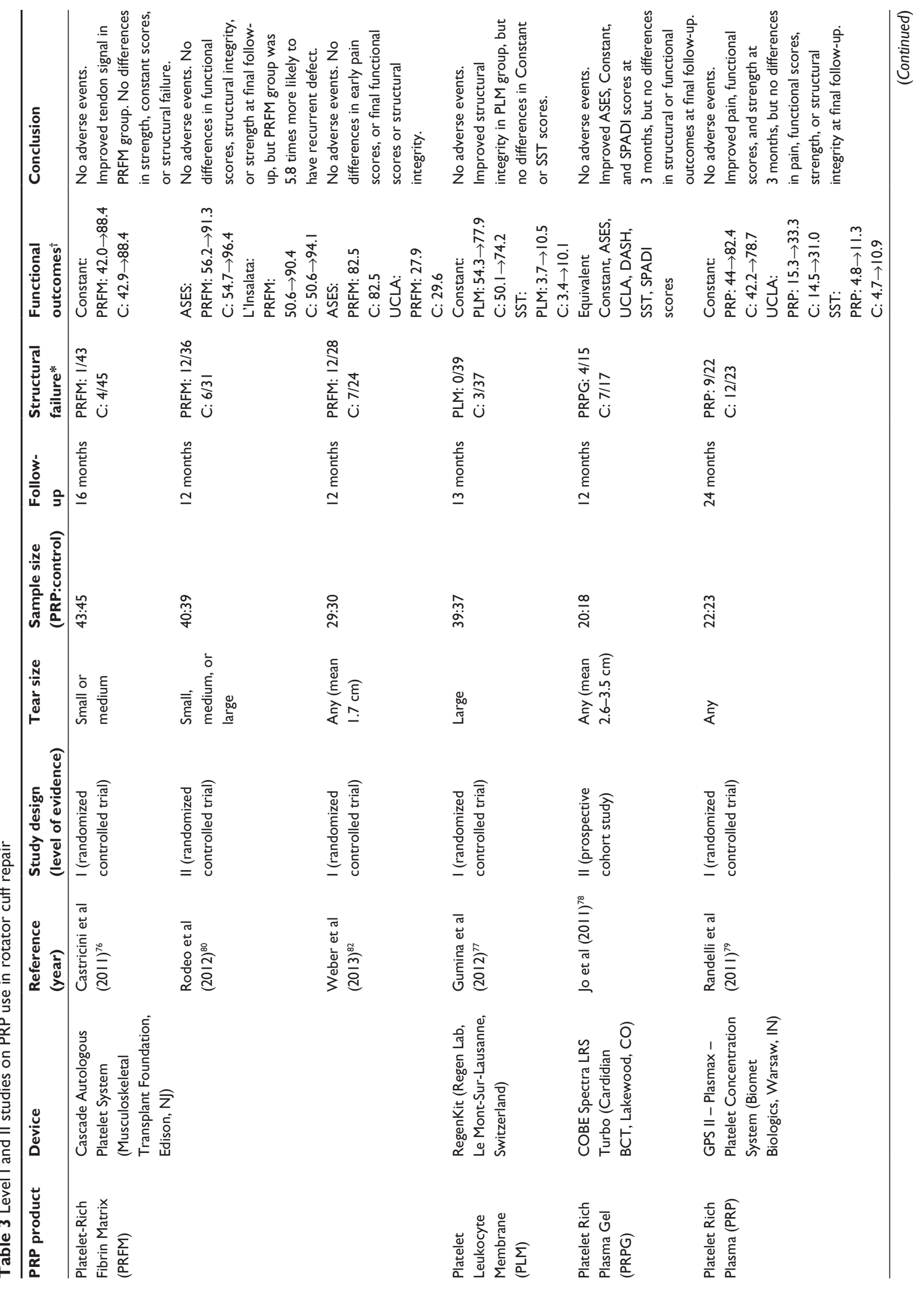




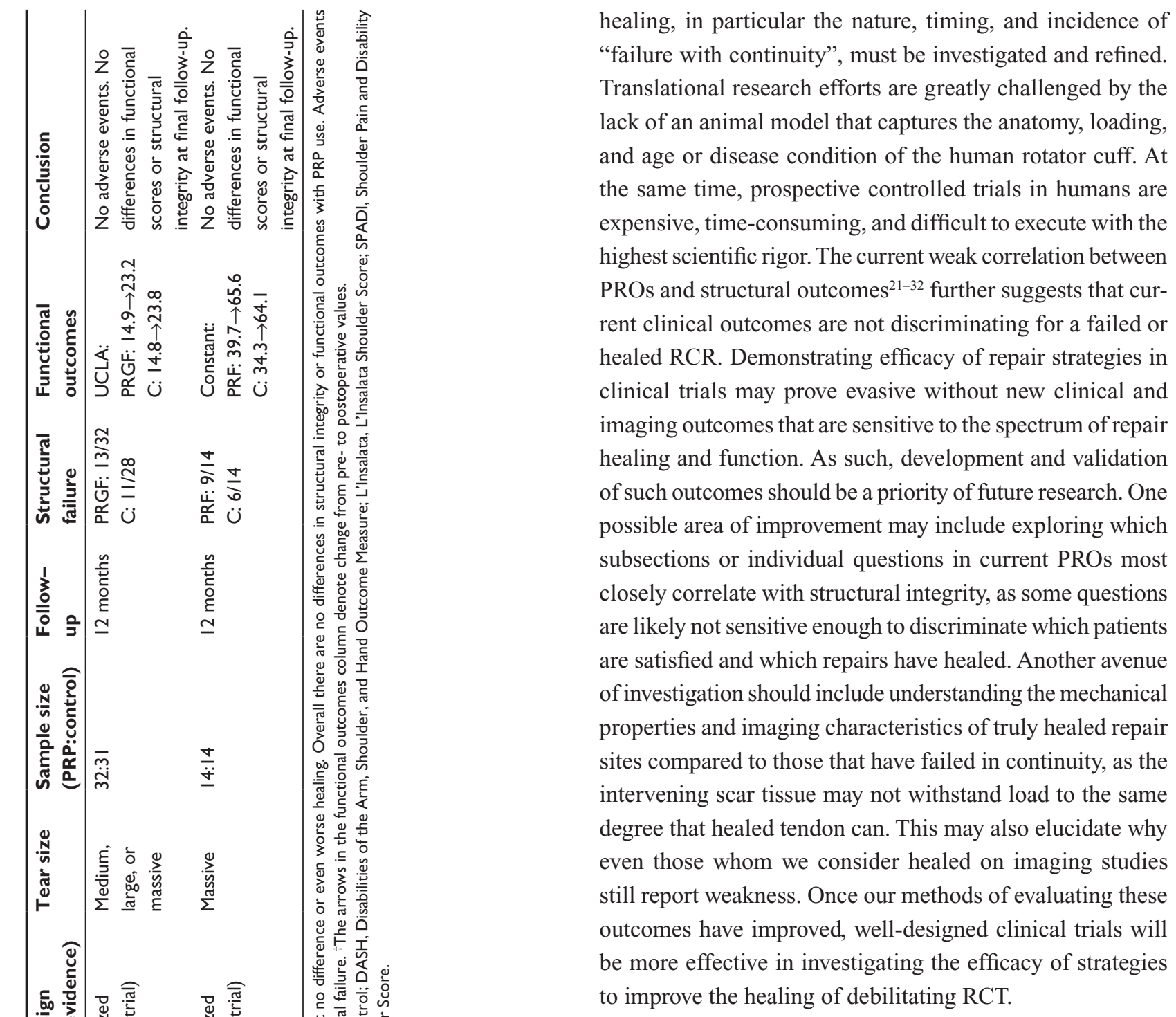

\section{Disclosure}

None of the disclosures of any author pertain to rotator cuff repair (the topic of this article). The authors report no conflicts of interest in this work.

\section{References}

1. Chakravarty K, Webley M. Shoulder joint movement and its relationship to disability in the elderly. $J$ Rheumatol. 1993;20(8):1359-1361.

2. Colvin AC, Egorova N, Harrison AK, Moskowitz A, Flatow EL. National trends in rotator cuff repair. J Bone Joint Surg Am. 2012;94(3): 227-233.

3. Vitale MA, Vitale MG, Zivin JG, Braman JP, Bigliani LU, Flatow EL. Rotator cuff repair: an analysis of utility scores and cost-effectiveness. J Shoulder Elbow Surg. 2007;16(2):18118-18117.

4. Tashjian RZ, Hollins AM, Kim HM, et al. Factors affecting healing rates after arthroscopic double-row rotator cuff repair. Am J Sports Med. 2010;38(12):2435-2442

5. Toussaint B, Schnaser E, Bosley J, Lefebvre Y, Gobezie R. Early structural and functional outcomes for arthroscopic double-row transosseous-equivalent rotator cuff repair. Am J Sports Med. 2011; 39(6):1217-1225. 
6. Koh KH, Kang KC, Lim TK, Shon MS, Yoo JC. Prospective randomized clinical trial of single- versus double-row suture anchor repair in 2- to 4-cm rotator cuff tears: clinical and magnetic resonance imaging results. Arthroscopy. 2011;27(4):453-462.

7. Levy O, Venkateswaran B, Even T, Ravenscroft M, Copeland S. Mid-term clinical and sonographic outcome of arthroscopic repair of the rotator cuff. J Bone Joint Surg Br. 2008;90(10):1341-1347.

8. Bishop J, Klepps S, Lo IK, Bird J, Gladstone JN, Flatow EL. Cuff integrity after arthroscopic versus open rotator cuff repair: a prospective study. J Shoulder Elbow Surg. 2006;15(3):290-299.

9. Boileau P, Brassart N, Watkinson DJ, Carles M, Hatzidakis AM, Krishnan SG. Arthroscopic repair of full-thickness tears of the supraspinatus: does the tendon really heal? J Bone Joint Surg Am. 2005;87(6): 1229-1240.

10. Charousset C, Grimberg J, Duranthon LD, Bellaiche L, Petrover D, Kalra K. The time for functional recovery after arthroscopic rotator cuff repair: correlation with tendon healing controlled by computed tomography arthrography. Arthroscopy. 2008;24(1):25-33.

11. DeFranco MJ, Bershadsky B, Ciccone J, Yum JK, Iannotti JP. Functional outcome of arthroscopic rotator cuff repairs: a correlation of anatomic and clinical results. J Shoulder Elbow Surg. 2007;16(6):759-765.

12. Klepps S. Prospective evaluation of the effect of rotator cuff integrity on the outcome of open rotator cuff repairs. Am J Sports Med. 2004;32(7): 1716-1722.

13. Lapner PL, Sabri E, Rakhra K, et al. A multicenter randomized controlled trial comparing single-row with double-row fixation in arthroscopic rotator cuff repair. J Bone Joint Surg Am. 2012;94(14): 1249-1257.

14. Franceschi F Ruzzini L, Longo UG, et al. Equivalent clinical results of arthroscopic single-row and double-row suture anchor repair for rotator cuff tears: a randomized controlled trial. Am J Sports Med. 2007;35(8): 1254-1260.

15. Gulotta LV, Nho SJ, Dodson CC, et al. Prospective evaluation of arthroscopic rotator cuff repairs at 5 years: part I - functional outcomes and radiographic healing rates. J Shoulder Elbow Surg. 2011;20(6): 934-940.

16. Harryman DT 2nd, Mack LA, Wang KY, Jackins SE, Richardson ML, Matsen FA 3rd. Repairs of the rotator cuff. Correlation of functional results with integrity of the cuff. J Bone Joint Surg Am. 1991;73(7): 982-989.

17. Huijsmans PE, Pritchard MP, Berghs BM, van Rooyen KS, Wallace AL, de Beer JF. Arthroscopic rotator cuff repair with double-row fixation. J Bone Joint Surg Am. 2007;89(6):1248-1557.

18. Lafosse L, Brozska R, Toussaint B, Gobezie R. The outcome and structural integrity of arthroscopic rotator cuff repair with use of the double-row suture anchor technique. J Bone Joint Surg Am . 2007;89(7): 1533-1541.

19. Cole BJ, McCarty LP 3rd, Kang RW, Alford W, Lewis PB, Hayden JK. Arthroscopic rotator cuff repair: prospective functional outcome and repair integrity at minimum 2-year follow-up. J Shoulder Elbow Surg. 2007;16(5):579-585.

20. Anderson K, Boothby M, Aschenbrener D, van Holsbeeck M. Outcome and structural integrity after arthroscopic rotator cuff repair using 2 rows of fixation: minimum 2-year follow-up. Am J Sports Med. 2006;34(12): 1899-1905.

21. Russell RD, Knight JR, Mulligan E, Khazzam MS. Structural integrity after rotator cuff repair does not correlate with patient function and pain: a meta-analysis. J Bone Joint Surg Am. 2014;96(4):265-271.

22. Sugaya H, Maeda K, Matsuki K, Moriishi J. Repair integrity and functional outcome after arthroscopic double-row rotator cuff repair. A prospective outcome study. J Bone Joint Surg Am. 2007;89(5):953-960.

23. Liem D, Lichtenberg S, Magosch P, Habermeyer P. Magnetic resonance imaging of arthroscopic supraspinatus tendon repair. J Bone Joint Surg Am. 2007;89(8):1770-1776.

24. Goutallier D, Postel JM, Bernageau J, Lavau L, Voisin MC. Fatty muscle degeneration in cuff ruptures. Clin Orthop Relat Res. 1994(304): 78-83.
25. Thomazeau H, Boukobza E, Morcet N, Chaperon J, Langlais F. Prediciton of rotator cuff repair results by magnetic resonance imaging. Clin Orthop Relat Res. 1997(344):275-283.

26. Prickett WD, Teefy SA, Galatz LM, Calfee RP, Middleton WD, Yamaguchi K. Accuracy of ultrasound imaging of the rotator cuff in shoulders that are painful postoperatively. J Bone Joint Surg Am. 2003;85-A(6):1084-1089.

27. Kyrölä K, Niemitukia L, Jaroma H, Väätäinen U. Long-term MRI findings in operated rotator cuff tear. Acta Radiol. 2004;45(5):526-533.

28. Fuchs B, Gilbart MK, Hodler J, Gerber C. Clinical and structural results of open repair of an isolated one-tendon tear of the rotator cuff. $J$ Bone Joint Surg Am. 2006;88(2):309-316.

29. Gladstone JN, Bishop JY, Lo IK, Flatow EL. Fatty infiltration and atrophy of the rotator cuff do not improve after rotator cuff repair and correlate with poor functional outcome. Am J Sports Med. 2007;35(5): 719-728.

30. Zandi H, Coghlan JA, Bell SN. Mini-incision rotator cuff repair: a longitudinal assessment with no deterioration of result up to nine years. J Shoulder Elbow Surg. 2006;15(2):135-139.

31. Posada A, Uribe JW, Hechtman KS, Tjin-A-Tsoi EW, Zvijac JE. Mini-deltoid splitting rotator cuff repair: do results deteriorate with time? Arthroscopy. 2000;16(2):137-141.

32. Galatz LM, Griggs S, Cameron BD, Iannotti JP. Prospective longitudinal analysis of postoperative shoulder function: a ten-year follow-up study of full-thickness rotator cuff tears. J Bone Joint Surg Am. 2001;83-A(7): 1052-1056.

33. Paxton ES, Teefey SA, Dahiya N, Keener JD, Yamaguchi K, Galatz LM. Clinical and radiographic outcomes of failed repairs of large or massive rotator cuff tears: minimum ten-year follow-up. J Bone Joint Surg Am. 2013;95(7):627-632.

34. Sugaya H, Maeda K, Matsuki K, Moriishi J. Functional and structural outcome after arthroscopic full-thickness rotator cuff repair: single-row versus dual-row fixation. Arthroscopy. 2005;21(11):1307-1316.

35. Baring TK, Cashman PP, Reilly P, Emery RJ, Amis AA. Rotator cuff repair failure in vivo: a radiostereometric measurement study. J Shoulder Elbow Surg. 2011;20(8):1194-1199.

36. McCarron JA, Derwin KA, Bey MJ, et al. Failure with continuity in rotator cuff repair "healing". Am J Sports Med. 2013;41(1): $134-141$.

37. Miller BS, Downie BK, Kohen RB, et al. When do rotator cuff repairs fail? Serial ultrasound examination after arthroscopic repair of large and massive rotator cuff tears. Am J Sports Med. 2011;39(10): 2064-2070.

38. Iannotti JP, Deutsch A, Green A, et al. Time to failure after rotator cuff repair: a prospective imaging study. J Bone Joint Surg Am. 2013;95(11): 965-971.

39. Hernigou P, Flouzat Lachaniette $\mathrm{CH}$, Delambre J, et al. Biologic augmentation of rotator cuff repair with mesenchymal stem cells during arthroscopy improves healing and prevents further tears: a casecontrolled study. Int Orthop. 2014;38(9):1811-1818.

40. Reing JE, Zhang L, Myers-Irvin J, et al. Degradation products of extracellular matrix affect cell migration and proliferation. Tissue Eng Part A. 2009;15(3):605-614.

41. Derwin KA, Badylak SF, Steinmann SP, Iannotti JP. Extracellular matrix scaffold devices for rotator cuff repair. J Shoulder Elbow Surg. 2010;19(3):467-476.

42. Derwin KA, Kovacevic D, Kim MS, Ricchetti ET. Biologic augmentation of rotator cuff healing. In: Nicholson GP, editor. Orthopaedic Knowledge Update: Shoulder and Elbow 4. Rosemont, IL: American Academy of Orthopaedic Surgeons; 2013:31-44.

43. McCarron JA, Milks RA, Chen X, Iannotti JP, Derwin KA. Improved time-zero biomechanical properties using poly-L-lactic acid graft augmentation in a cadaveric rotator cuff repair model. J Shoulder Elbow Surg. 2010;19(5):688-696.

44. Barber FA, Herbert MA, Boothby MH. Ultimate tensile failure loads of a human dermal allograft rotator cuff augmentation. Arthroscopy. 2008;24(1):20-24 
45. McCarron JA, Milks RA, Mesiha M, et al. Reinforced fascia patch limits cyclic gapping of rotator cuff repairs in a human cadaveric model. J Shoulder Elbow Surg. 2012;21(12):1680-1686.

46. Sahoo S, Greeson CB, McCarron JA, et al. Effect of pretension and suture needle type on mechanical properties of acellular human dermis patches for rotator cuff repair. J Shoulder Elbow Surg. 2012;21(10): $1413-1421$

47. Iannotti JP, Codsi MJ, Kwon YW, Derwin K, Ciccone J, Brems JJ. Porcine small intestine submucosa augmentation of surgical repair of chronic two-tendon rotator cuff tears. A randomized, controlled trial. J Bone Joint Surg Am. 2006;88(6):1238-1244.

48. Walton JR, Bowman NK, Khatib Y, Linklater J, Murrell GA. Restore orthobiologic implant: not recommended for augmentation of rotator cuff repairs. J Bone Joint Surg Am. 2007;89(4):786-791.

49. Sclamberg SG, Tibone JE, Itamura JM, Kasraeian S. Six-month magnetic resonance imaging follow-up of large and massive rotator cuff repairs reinforced with porcine small intestinal submucosa. $J$ Shoulder Elbow Surg. 2004;13(5):538-541.

50. Pedowitz RA, Yamaguchi K, Ahmad CS, et al; American Academy of Orthopaedic Surgeons. Optimizing the management of rotator cuff problems. J Am Acad Orthop Surg. 2011;19(6):368-379.

51. Soler JA, Gidwani S, Curtis MJ. Early complications from the use of porcine dermal collagen implants (Permacol) as bridging constructs in the repair of massive rotator cuff tears. A report of 4 cases. Acta Orthop Belg. 2007;73(4):432-436.

52. Badhe SP, Lawrence TM, Smith FD, Lunn PG. An assessment of porcine dermal xenograft as an augmentation graft in the treatment of extensive rotator cuff tears. J Shoulder Elbow Surg. 2008;17(1 Suppl): 35S-39S.

53. Burkhead WZ, Schiffern SC, Krishnan SG. Use of GraftJacket as an augmentation for massive rotator cuff tears. Semin Arthroplasty. 2007;18(1):11-18.

54. Dopirak R, Bond JL, Snyder SJ. Arthroscopic total rotator cuff replacement with an acellular human dermal allograft matrix. Int $J$ Shoulder Surg. 2007;1(1):7-15.

55. Bond JL, Dopirak RM, Higgins J, Burns J, Snyder SJ. Arthroscopic replacement of massive, irreparable rotator cuff tears using a GraftJacket allograft: technique and preliminary results. Arthroscopy. 2008; 24(4):403-409. e1.

56. Wong I, Burns J, Snyder S. Arthroscopic GraftJacket repair of rotator cuff tears. J Shoulder Elbow Surg. 2010;19(2 Suppl):104-109.

57. Barber FA, Burns JP, Deutsch A, Labbe MR, Litchfield RB. A prospective, randomized evaluation of acellular human dermal matrix augmentation for arthroscopic rotator cuff repair. Arthroscopy. 2012;28(1): $8-15$.

58. Ciampi P, Scotti C, Nonis A, et al. The benefit of synthetic versus biological patch augmentation in the repair of posterosuperior massive rotator cuff tears: a 3-year follow-up study. Am J Sports Med. 2014; 42(5):1169-1175.

59. Encalada-Diaz I, Cole BJ, Macgillivray JD, et al. Rotator cuff repair augmentation using a novel polycarbonate polyurethane patch: preliminary results at 12 months' follow-up. J Shoulder Elbow Surg. 2011;20(5): 788-794.

60. Petriccioli D, Bertone C, Marchi G, Mujahed I. Open repair of isolated traumatic subscapularis tendon tears with a synthetic soft tissue reinforcement. Musculoskelet Surg. 2013;97(Suppl 1):63-68.

61. Proctor CS. Long-term successful arthroscopic repair of large and massive rotator cuff tears with a functional and degradable reinforcement device. J Shoulder Elbow Surg. 2014;23(10):1508-1513.

62. Petrie MJ, Ismaiel AH. Treatment of massive rotator-cuff tears with a polyester ligament (LARS) patch. Acta Orthop Belg. 2013;79(6): 620-625.

63. Del Fabbro M, Bortolin M, Taschieri S, Weinstein R. Is platelet concentrate advantageous for the surgical treatment of periodontal diseases? A systematic review and meta-analysis. J Periodontol. 2011;82(8): $1100-1111$
64. Marx RE, Carlson ER, Eichstaedt RM, Schimmele SR, Strauss JE, Georgeff KR. Platelet-rich plasma: growth factor enhancement for bone grafts. Oral Surg Oral Med Oral Pathol Oral Radiol Endod. 1998;85(6): 638-646.

65. Knighton DR, Ciresi KF, Fiegel VD, Austin LL, Butler EL. Classification and treatment of chronic nonhealing wounds. Successful treatment with autologous platelet-derived wound healing factors (PDWHF). Ann Surg. 1986;204(3):322-330.

66. Sheth U, Simunovic N, Klein G, et al. Efficacy of autologous plateletrich plasma use for orthopaedic indications: a meta-analysis. $J$ Bone Joint Surg Am. 2012;94(4):298-307.

67. Foster TE, Puskas BL, Mandelbaum BR, Gerhardt MB, Rodeo SA. Platelet-rich plasma: from basic science to clinical applications. Am J Sports Med. 2009;37(11):2259-2272.

68. Boswell SG, Cole BJ, Sundman EA, Karas V, Fortier LA. Plateletrich plasma: a milieu of bioactive factors. Arthroscopy. 2012;28(3): 429-439.

69. Hall MP, Band PA, Meislin RJ, Jazrawi LM, Cardone DA. Platelet-rich plasma: current concepts and application in sports medicine. J Am Acad Orthop Surg. 2009;17(10):602-608.

70. Castillo TN, Pouliot MA, Kim HJ, Dragoo JL. Comparison of growth factor and platelet concentration from commercial platelet-rich plasma separation systems. Am J Sports Med. 2011;39(2):266-271.

71. Kobayashi M, Itoi E, Minagawa H, et al. Expression of growth factors in the early phase of supraspinatus tendon healing in rabbits. $J$ Shoulder Elbow Surg. 2006;15(3):371-377.

72. Civinini R, Macera A, Nistri L, Redl B, Innocenti M. The use of autologous blood-derived growth factors in bone regeneration. Clin Cases Miner Bone Metab. 2011;8(1):25-31.

73. Mazzocca AD, McCarthy MB, Chowaniec DM, et al. Platelet-rich plasma differs according to preparation method and human variability. J Bone Joint Surg Am. 2012;94(4):308-316.

74. Dohan Ehrenfest DM, Bielecki T, Mishra A, et al. In search of a consensus terminology in the field of platelet concentrates for surgical use: plateletrich plasma (PRP), platelet-rich fibrin (PRF), fibrin gel polymerization and leukocytes. Curr Pharm Biotechnol. 2012;13(7):1131-1137.

75. Marx RE. Platelet-rich plasma: evidence to support its use. J Oral Maxillofac Surg. 2004;62(4):489-496.

76. Castricini R, Longo UG, De Benedetto M, et al. Platelet-rich plasma augmentation for arthroscopic rotator cuff repair: a randomized controlled trial. Am J Sports Med. 2011;39(2):258-265.

77. Gumina S, Campagna V, Ferrazza G, et al. Use of platelet-leukocyte membrane in arthroscopic repair of large rotator cuff tears: a prospective randomized study. J Bone Joint Surg Am. 2012;94(15): $1345-1352$

78. Jo CH, Shin JS, Lee YG, et al. Platelet-rich plasma for arthroscopic repair of large to massive rotator cuff tears: a randomized, single-blind, parallel-group trial. Am J Sports Med. 2013;41(10):2240-2248.

79. Randelli P, Arrigoni P, Ragone V, Aliprandi A, Cabitza P. Platelet rich plasma in arthroscopic rotator cuff repair: a prospective RCT study, 2-year follow-up. J Shoulder Elbow Surg. 2011;20(4):518-528.

80. Rodeo SA, Delos D, Williams RJ, Adler RS, Pearle A, Warren RF. The effect of platelet-rich fibrin matrix on rotator cuff tendon healing: a prospective, randomized clinical study. Am J Sports Med. 2012;40(6): 1234-1241.

81. Ruiz-Moneo P, Molano-Munoz J, Prieto E, Algorta J. Plasma rich in growth factors in arthroscopic rotator cuff repair: a randomized, doubleblind, controlled clinical trial. Arthroscopy. 2013;29(1):2-9.

82. Weber SC, Kauffman JI, Parise C, Weber SJ, Katz SD. Platelet-rich fibrin matrix in the management of arthroscopic repair of the rotator cuff: a prospective, randomized, double-blinded study. Am J Sports Med. 2013;41(2):263-270.

83. Antuna S, Barco R, Martinez Diez JM, Sanchez Marquez JM. Plateletrich fibrin in arthroscopic repair of massive rotator cuff tears: a prospective randomized pilot clinical trial. Acta Orthop Belg. 2013;79(1): $25-30$. 
84. Barber FA, Hrnack SA, Snyder SJ, Hapa O. Rotator cuff repair healing influenced by platelet-rich plasma construct augmentation. Arthroscopy. 2011;27(8):1029-1035.

85. Bergeson AG, Tashjian RZ, Greis PE, Crim J, Stoddard GJ, Burks RT. Effects of platelet-rich fibrin matrix on repair integrity of at-risk rotator cuff tears. Am J Sports Med. 2012;40(2):286-293.

86. Zhao JG, Zhao L, Jiang YX, Wang ZL, Wang J, Zhang P. Platelet-rich plasma in arthroscopic rotator cuff repair: a meta-analysis of randomized controlled trials. Arthroscopy. 2015;31(1):125-135.

87. Ellera Gomes JL, da Silva RC, Silla LM, Abreu MR, Pellanda R. Conventional rotator cuff repair complemented by the aid of mononuclear autologous stem cells. Knee Surg Sports Traumatol Arthrosc. 2012;20(2):373-377.

88. Lenart BA, Martens KA, Kearns KA, Gillespie RJ, Zoga AC, Williams GR. Treatment of massive and recurrent rotator cuff tears augmented with a poly-1-lactide graft, a preliminary study. J Shoulder Elbow Surg. 2015;24(6):915-921.

89. Agrawal V. Healing rates for challenging rotator cuff tears utilizing an acellular human dermal reinforcement graft. Int J Shoulder Surg. 2012; 6(2):36-44.

90. Rotini R, Marinelli A, Guerra E, et al. Human dermal matrix scaffold augmentation for large and massive rotator cuff repairs: preliminary clinical and MRI results at 1-year follow-up. Musculoskelet Surg. 2011 95(Suppl 1):S13-S23.
91. Cho CH, Lee SM, Lee YK, Shin HK. Mini-open suture bridge repair with porcine dermal patch augmentation for massive rotator cuff tear: surgical technique and preliminary results. Clin Orthop Surg. 2014;6(3): 329-335.

92. Gupta AK, Hug K, Berkoff DJ, et al. Dermal tissue allograft for the repair of massive irreparable rotator cuff tears. Am J Sports Med. 2012; 40(1):141-147.

93. Mihata T, Lee TQ, Watanabe C, et al. Clinical results of arthroscopic superior capsule reconstruction for irreparable rotator cuff tears Arthroscopy. 2013;29(3):459-470.

94. Mori D, Funakoshi N, Yamashita F. Arthroscopic surgery of irreparable large or massive rotator cuff tears with low-grade fatty degeneration of the infraspinatus: patch autograft procedure versus partial repair procedure. Arthroscopy. 2013;29(12):1911-1921.

95. Gupta AK, Hug K, Boggess B, Gavigan M, Toth AP. Massive or 2-tendon rotator cuff tears in active patients with minimal glenohumeral arthritis: clinical and radiographic outcomes of reconstruction using dermal tissue matrix xenograft. Am J Sports Med. 2013;41(4):872-879.
Orthopedic Research and Reviews

\section{Publish your work in this journal}

Orthopedic Research and Reviews is an international, peer-reviewed, open access journal focusing on the patho-physiology of the musculoskeletal system, trauma, surgery and other corrective interventions to restore mobility and function. Advances in new technologies, materials, techniques and pharmacological agents are particularly welcome. The journal welcomes

\section{Dovepress}

original research, clinical studies, reviews \& evaluations, expert opinion and commentary, case reports and extended reports. The manuscript management system is completely online and includes a very quick and fair peer-review system, which is all easy to use. Visit http://www.dovepress. com/testimonials.php to read real quotes from published authors. 